\title{
BIOLOGICAL INTEGRITY OF BISON EPIDIDYMAL SPERM UNDER CRYOCONSERVATION AND LONG STORAGE
}

\section{B.S. IOLCHIEV 1 , A.I. ABILOV1, A.V. TADZHIEVA², V.A. BAGIROV1, Sh.N. NASIBOV ${ }^{3}$, I.N. SHAIDULLIN1, P.M. KLENOVITSKIY1, N.A. KOMBAROVA ${ }^{4}$, M.A. ZHILINSKIY ${ }^{1}$}

\author{
${ }^{1}$ L.K. Ernst All-Russian Research Institute of Animal Husbandry, Federal Agency of Scientific Organizations, 60, \\ pos. Dubrovitsy, Podolsk District, Moscow Province, 142132 Russia, e-mail baylar1@yandex.ru (corresponding \\ author); \\ 2Peoples' Friendship University of Russia, 6, ul. Miklukho-Maklaya, Moscow, 117198 Russia; \\ ${ }^{3}$ All-Russian Research Institute of Agricultural Biotechnology, Federal Agency of Scientific Organizations, 42, ul. \\ Timiryazevskaya, Moscow, 127550 Russia; \\ ${ }^{4}$ Head Centre for Reproduction of Farm Animals, 2, ul. Tsentralnaya, pos. Bykovo, Podolsk municipal district, Mos- \\ cow Province, 142143 Russia
}

ORCID:

Iolchiev B.S. orcid.org/0000-0001-5386-7263

Bagirov V.A. orcid.org/0000-0001-5398-8815

Shaidullin I.N. orcid.org/0000-0002-5857-4993

Klenovitskiy P.M. orcid.org/0000-0003-2266-1275

The authors declare no conflict of interests

Acknowledgements:

Supported financially by RAS Presidium Program № IV.13.3

Received December 30, 2016

\section{Abstract}

Conservation of biodiversity is one of the global challenges of the modern world. The preservation of animal genetic resources is considered essential for the food supply, since sustainable food production appears to be the greatest problem due to the human population growth, depletion of the Earth's natural resources, and many species becoming endangered. In situ and ex situ methods of preservation of the species (i.e. in/out of their natural habitats, respectively) are two major approaches to animal biodiversity conservation. Ex situ strategy involves the techniques for the genetic material cryopreservation. Cryopreservation of the wildlife biomaterials allows to use these genetic resources not only for the conservation and the renewal, but also for the introduction into the genotype of the farm animals. The bison (Bison bonasus) is identified as the rare and endangered species. At present, the free-living bison population in Russia comprises more than 1500 animals. A research concept of the Russian bison gene pool preservation includes creating cryo-preserved pool of bison spermatozoa. In this paper we report findings on biological adequacy of the cryopreserved epididymal bison semen after the long storage (for more than 20 years). The sperm samples were collected postmortem from the testicular appendages of four bison males sustained the injuries incompatible with life or culled and used for hunting. For the assessment of semen motility we used a computerassisted semen analysis (CASA) device; the DNA fragmentation index was assessed in AO-test with the acridine orange staining. The acrosomal integrity was studied by Diff-Quik staining method. It was shown that the semen quality parameters differed significantly due to the individual peculiarities of the bison. The spermatozoa of A + B grade which performed good motility and rectilinear motion reached more than $28 \%$ in the semen of the males Mutfil and Morus, while in the Avel's and Misir's semen over $67 \%$ spermatozoa were non-motile and $12.1 \%$ and $10.4 \%$ spermatozoa exhibited rotational and vibrational motions, respectively. The frequency of spermatozoa with pathomorphological changes significantly varied depending on the individual properties of the bison, with the greatest and the lowest values of $14.6 \%$ and $6.8 \%$, respectively. The DNA fragmentation index reflecting sperm chromatin integrity can depend on the numerous biotic and abiotic factors and may vary in great ranges. In our surveys, it varied from $7 \%$ to $86 \%$. For all the morphometric parameters, except the head width, the bison spermatozoa were inferior to the spermatozoa of the bulls though the differences between animal groups were not statistically significant. However, the area of the spermatozoa head in bulls was $3.14 \mu \mathrm{m}^{2}$ larger than that of bison.

Keywords: European bison, Bison bonasus, cryopreservation, spermatozoa, acrosome, index of DNA fragmentation, chromatin

At present, preserving flora and fauna is one of the global challenges to 
mankind [1, 2]. Due to unfavorable environment, anthropogenic, economic and other factors, most of which are also man-caused, some species are endangered. It is proved that the stability of the community is the higher the more the number of its constituent species, therefore, the conservation of biodiversity is the only mechanism for ensuring the stability of life on Earth [3, 4]. In addition, with a high rate of population growth and limited resources, the provision of food and raw materials for industry is becoming a serious problem. Its effective solution is in the breeding highly productive animals and the wild animal domestication. The genetic diversity of the source material affects the success of breeding. Long selection is accompanied by an increase in homozygosity, which, in turn, leads to a number of disorders, i.e. to a decrease in resistance, the appearance of hereditary diseases, etc. To increase the heterozygosity, a new genetic pool is often required, which could be find among wild relatives of domestic animals [5-9].

There are two main strategies for preserving gene pool: in situ (the management of species in the natural habitat or breeds of domestic animals under breeding conditions) and ex situ (conservation of components of biological diversity outside their natural habitats, e.g. in nursery-gardens, zoos, etc., or through cryopreservation of genetic material). The in situ method suggests the breeding and management of animals and poultry in special gene pool farms and is economically costly. The ex situ method is important for species whose reintroduction is not possible in the near future [10-14]. In many countries, ex situ conservation is an integral part of the environmental strategy [15]. Depending on the purpose and objective, the biological material for cryopreservation can be embryos, animal tissues, male (spermatozoa), and female (oocyte) germ cells [16-22]. Cryobank of genetic resources of wild fauna can be used to preserve species, as well as to create new selection types and breeds.

Bison (Bison bonasus L.), a wild forest bull, refers to rare endangered species. This is the largest ungulate animal, the only wild species of the subfamily Bovinae, inhabiting the European continent [23-25]. At the beginning of the 20th century, the free-living populations of bison were almost lost. As a result of prolonged scientific and selective work, the number of bison from 1927 to 2000 increased by more than 70 times and now amounts to more than 3,500 thousand individuals; in Russia, there are about 1500 free-living bison.

Cryotechnologies and artificial reproduction in vitro used in preservation and restoration of rare species are the methods recommended by the Convention on Biological Diversity and international organizations [26-28]. At the L.K. Ernst All-Russian Research Institute of Animal Husbandry, the technique of sampling and cryopreservation of bison epididymal semen has been developed, which made it possible to create a semen cryobank of the bison inhabiting the Prioksko-Terrasnaya and Oka state natural biosphere reserves [29]. Three generations of hybrid animals were produced using cryopreserved epididymal semen. In particular, four heifers were born after artificial insemination of black-and-white cows, and $F_{1}$ and $F_{2}$ hybrids from different crossing with dairy (black-and-white, Holstein) and meat (Aberdeen-Angus) breeds were studied [30, 31].

The epididymal and ejaculated semen are significantly different both morphologically and functionally. Epididymal spermatozoa are immobile, and have low metabolism. The motility of spermatozoa is initiated after ejaculation, as a result of which metabolic processes are activated. The cryoresistance of spermatozoa with a low metabolism is higher.

Cryopreservation of spermatozoa, including those extracted from epididymis, uses media that enhance metabolism. It is known that the last stage of condensation of chromatin in the nucleus of spermatozoa occurs after ejaculation, therefore, this parameter is lower in the germ cells extracted from the epi- 
didymis than in ejaculated cells. That is, the probability of damage to genetic material during freezing-thawing in the nuclei of spermatozoa from epididymis is higher than that in ejaculated semen [32]. Cryopreservation affects the morphometric parameters of spermatozoa. As a result of freezing-thawing, the cell size decrease, especially the area and perimeter of the head [33-36]. Cryopreservation also affects the ultrastructure of spermatozoa [37-40]. Currently, common techniques are sperm cryopreservation in straws and in granules.

We first investigated the effect of cryopreservation and storage on morphometric and morphofunctional properties of bison semen.

The aim of the present work was to study biological usefulness of the frozen-thawed epididymal semen of the bison after a long (more than 20 years) storage.

Technique. Since 1998, epididymal semen has been sampled from four male bison in Prioksko-Terrasny and Oka state natural biosphere reserves. Postmortem Extraction was carried out from the appendage of testis in the animals with life-incompatible injuries or culled (intended for hunting). The contents of the epididymis tail were homogenized in a synthetic medium and filtered to remove cell admixtures. The content and mobility of freshly received epididymal spermatozoa in the sample was determined by the method of assessing semen quality in bull sires. The semen was frozen in granules as per the technology of bull sperm cryopreservation [41].

A routine evaluation of the frozen-thawed semen was carried out in CASA, a computer-assisted semen analysis system. DNA fragmentation was assessed with acridine orange (AO-test) and fluorescence microscopy. The acrosomes were studied using Diff Quik staining (42-44).

The of frozen-thawed spermatozoa motility was determined with Zoosperm 1.0 software (VideoTest, Russia), Makler counting chamber (Israel) and a Nikon Eclipse Ni microscope (Nikon Corp., Japan) based on video recording for 1 second of three fields as an average for 3 samples.

Data processing and classification of spermatozoa was performed in an automatic mode based on the following indices: VAP as the average velocity of the head moving along the average path of motion, $\mu \mathrm{m} / \mathrm{s}$; VSL as the speed of rectilinear movement of the head (the average velocity of the head of the spermatozoon along the straight segment between the start and the end points of the trajectory), $\mu \mathrm{m} / \mathrm{s}$; VCL as average speed of spermatozoa movement along the real trajectory, $\mu \mathrm{m} / \mathrm{s}$; ALH as the average deviation of the head (amplitude of lateral displacement of the sperm head from the trajectory), $\mu \mathrm{m}$; BCF as frequency of oscillatory averaged movements (frequency of intersections), $\mathrm{Hz}$; the average frequency of the intersection of the curvilinear trajectory of the sperm movement by its averaged trajectory per time unit.

The straightness of the mean trajectory $(\%)$ was STR $=$ VSL/VAP $\times 100$, a degree of undulation of the tracks (the magnitude of the variation of the true trajectory with respect to the average trajectory, \%) was LIN $=$ VSL/VCL $\times 100$.

Depending on these parameters, the spermatozoa were divided into four classes, A (rectilinar speed not less than $25 \mu \mathrm{m} / \mathrm{s}$, or a distance per second equal to their length); B (with slow rectilinear motion at less than $25 \mu \mathrm{m} / \mathrm{s}$ ); C (with circus or oscillating motility); D (immobile).

Since it is impossible to obtain ejaculated bison semen in natural habitat of th animals, the bull semen $(n=4)$ was compared to the semen of their relatives, the Holstein bulls $(n=15)$, by morphometric parameters. The sperm of bull sires were cryopreserved in straws and stored no more than 2 years. Bison semen was stored over 20 years.

The data were mathematically processed using variation statistics in the 
Microsoft Excel software package. The tables show average values $(X)$ and standard errors $(x)$.

1. The percentage of spermatozoa of different classes in the frozen-thawed bison (Bison bonasus L.) semen $(X \pm x)$

\begin{tabular}{l|r|r|c|c}
\hline \multirow{2}{*}{$\begin{array}{l}\text { Bison } \\
\text { name }\end{array}$} & \multicolumn{4}{|c}{ Class } \\
\cline { 2 - 5 } & $\mathrm{A}$ & $\mathrm{B}$ & $\mathrm{C}$ & $\mathrm{D}$ \\
\hline Mutfil & $10.3 \pm 0.2$ & $18.8 \pm 0.9$ & $20.3 \pm 1.2$ & $50.6 \pm 1.6$ \\
Avel & $8.4 \pm 0.1$ & $12.3 \pm 0.7$ & $12.1 \pm 0.9$ & $67.2 \pm 1.8$ \\
Morus & $6.3 \pm 0.2$ & $22.3 \pm 0.8$ & $13.2 \pm 0.6$ & $58.2 \pm 2.1$ \\
Misir & $8.3 \pm 0.2$ & $13.4 \pm 1.2$ & $10.4 \pm 0.8$ & $67.9 \pm 3.6$ \\
\multicolumn{4}{l|}{ N o t e. For description of the classes see } & Technique section. \\
\hline
\end{tabular}

method [45-47].

2. Morphometric parameters of frozen-thawed spermatozoa of bison (Bison bonasus L.) and Holstein bull sires $(X \pm x)$

\begin{tabular}{l|c|c}
\hline \multicolumn{1}{c}{ Parameter } & Bisons $(n=4)$ & Bulls $(n=15)$ \\
\hline Spermatozoon length, $\mu \mathrm{m}$ & $65.90 \pm 1.57$ & $68.3 \pm 0.98$ \\
Head length, $\mu \mathrm{m}$ & $8.46 \pm 0.66$ & $9.58 \pm 0.28$ \\
Head width, $\mu \mathrm{m}$ & $4.72 \pm 0.42$ & $4.60 \pm 0.12$ \\
Perimeter of the head, $\mu \mathrm{m}$ & $23.95 \pm 1.55$ & $24.61 \pm 0.36$ \\
Head area, $\mu \mathrm{m}^{2}$ & $38.46 \pm 1.67$ & $41.6 \pm 1.32^{*}$ \\
Length of flagellum, $\mu \mathrm{m}$ & $57.34 \pm 1.96$ & $58.72 \pm 0.36$ \\
\cline { 1 - 1 }${ }^{*} \mathrm{P} \leq 0.05$. & & \\
\hline
\end{tabular}

Results. The number of spermatozoa with rectilinear motion in native and frozenthawed semen depends on a variety of factors, such as individual characteristics of the animals, species, age, cryoconservation technology, diluents and cryoprotectants used, thawing

The semen differed significantly in the number of $\mathrm{A}$ and B spermatozoa (Table 1). The main factors that influenced the activity of spermatozoa were the age, individual characteristics of the bison and the duration of semen storage, since the medium composition and cryopreservation-thawing technology

for all samples were the same. In frozen-thawed semen of Mutfil and Morus, more than $28 \%$ spermatozoa were of A + B classes; in Avel and Misir, more than $67 \%$ spermatozoa were immobile, and those with circus and oscillatory motility amounted to 12.1 and $10.4 \%$, respectively.

In collecting and cryopreservation of the semen, different technologies were used in bulls and bison. Ejaculated spermatozoa and those extracted from epididymis significantly differed. For all the morphometric parameters, except for the width of the head, the bison spermatozoa were inferior to the bull spermatozoa. It should be noted that the differences between the groups in the indicators were not statistically significant, except for the area of the sperm head, i.e. in bulls, it was $3.14 \mu \mathrm{m}^{2}$ larger than that in bison (Table 2).

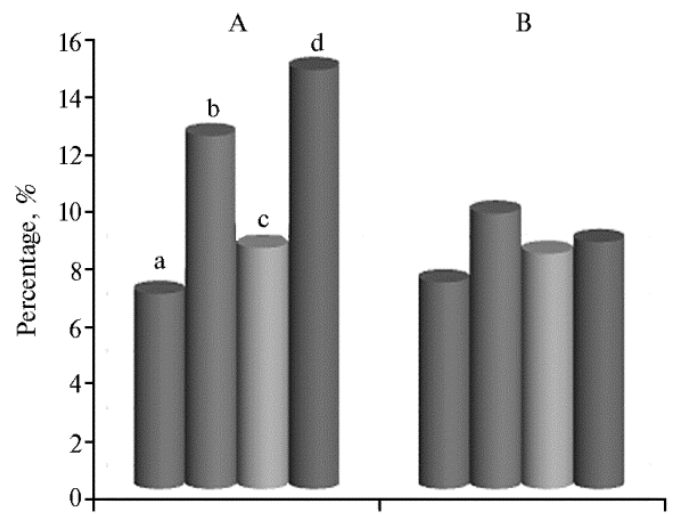

Fig. 1. The percentage of spermatozoa with morphological disorders (A) and damaged acrosome (B) in the frozen-thawed semen of four bison (Bison bonasus L.): a - Mutfil, b - Avel, c - Morus, d Misir (stored for more than 20 years).

disorders and a damaged acrosome (Fig. 1).
We also studied organelles and morphological structures of bison spermatozoa. The anomalous structure of spermatozoa is due to the genetic component [48], seasonal and environmental factors, individual predisposition [49-52], and age [53-56].

Chromatin is one of the most important structural elements of spermatozoa. The cause of idiopathic infertility may be a high index of DNA fragmentation in chromatin [57-61]. The DNA fragmentation in spermatozoa also depends on numerous biotic and abiotic factors [62-69].

A significant difference was found between the bison in the ratio of spermatozoa with morphological 


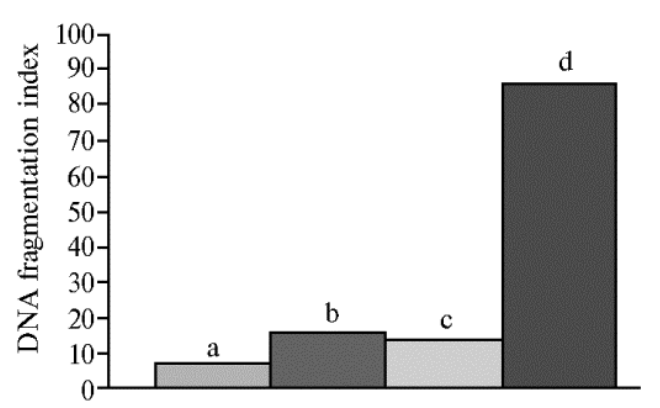

Fig. 2. The DNA fragmentation index in chromatin of spermatozoa in the frozen-thawed semen of four bison (Bison bonasus L.): a - Mutfil, b - Avel, c Morus, $\mathrm{d}-$ Misir (stored for more than 20 years).

The frequency of spermatozoa with abnormal morphology was greatest in Misir (14.6\%), and the lowest in Mutfil $(6.8 \%)$. In the latter, the frequency of damaged acrosomes was insignificant compared to other bison and amounted to $7.2 \%$.

The DNA fragmentation index in the chromatin of spermatozoa varied significantly among the samples (Fig. 2). High fragmentation was observed in Misir (more than $86 \%$ ), and the least was found in Mutfil (7 \%).

Thus, the indices characterizing the biological integrity of spermatozoa in the frozen-thawed bison semen stored for more than 20 years depended on the animal individual characteristics. The number of spermatozoa with abnormal morphology varied from 6.8 to $14.6 \%$, the DNA fragmentation was from 7 to $86 \%$. The results of our studies show that the methods of sampling and cryopreservation technology affect the morphometric parameters of spermatozoa that were lower in the frozen-thawed epididymal semen as compared to ejaculated sperm.

\section{REFEREN CES}

1. Bagirov V.A., Ernst L.K., Klenovitski i P.M., Zinov'eva N.A. Tsitologiya, 2004, 46(9): 767-768. Available http://elibrary.ru/item.asp?id=21635266. No date (in Russ.).

2. Gusev M.V., M e le khova O.P., Rom nova E.P. Cokhranenie $i$ vosstanovlenie bioraznoobraziya [Preservation and restoration of biodiversity]. Moscow, 2002 (in Russ.).

3. R y u m i n a E.V., K a r a c h e v t s e v I.L. Ekonomika prirodopol'zovaniya, 2005, 1: 112-118 (in Russ.).

4. T is h k v A.A. Biosfernye funktsii prirodnykh ekosistem Rossii [Biospheric functions of natural ecosystems sht Russia]. Moscow, 2005 (in Russ.).

5. Sh a idulli n I.N. Biologicheskie osobennosti akklimatizatsii ovets $i$ gibridizatsii ikh so snezhnym baranom Ovis nivicola nivicola $v$ usloviyakh Kamchatki. Doktorskaya dissertatsiya [Biological features of sheep under acclimatization in Kamchatka and hybridization with Ovis nivicola nivicola. DSci Thesis]. Dubrovitsy, 1994 (in Russ.).

6. B agi rov V.A., Ernst L.K., N a s ibov S.N., K le novitskiy P.M., I olchiev B.S., Zinov'eva N.A. Dostizheniya nauki $i$ tekhniki APK, 2009, 7: 54-56. Available http://elibrary.ru/item.asp?id=13002971. No date (in Russ.).

7. I o l chiev B.S., Kle novitski i P.M., B agi rov V.A., Voevodi n V.A., Kononov V.P., N a sib ov Sh.N. Problemy biologii produktivnykh zhivotnykh, 2011, 1: 29-31. Available http://elibrary.ru/it-em.asp?id=16092095. No date (in Russ.).

8. N a sibov Sh.N., I o $1 \mathrm{c}$ hi ev B.S., K l e novitski y P.M., B a gi rov V.A., Vo e vo di in V.A., Zi nov'eva N.A. Dostizheniya nauki i tekhniki APK, 2010, 9: 50-51. Available http://elibrary.ru/item.asp?id=15253713. No date.

9. B a girov V.A., Gladyr' E.A., Ernst L.K., Klenovitskii P.M., Zinov'e v a N.A., Nasibov Sh.N. [Preservation and efficient use of genetic resources of yak (Bos mutus)]. Agricultural Biology, 2009, 2: 37-42 (in Russ.).

10. R y a b o v a E.V. Bioraznoobrazie $i$ sposoby ego sokhraneniya [Biodiversity - the ways to preservation]. Kirov, 2012 (in Russ.).

11. Pereira R.M., M a rques C.C. Animal oocyte and embryo cryopreservation. Cell and Tissue Banking, 2008, 9(4): 267-277 (doi: 10.1007/s10561-008-9075-2).

12. Roldan E.R., Gomendio M., Garde J.J., Espeso G., Ledda S., B e rlingu e r F., D e $101 \mathrm{mo}$ A., S o le r A.J., Arregui L., C respo C., Go nzales R. Inbreeding and reproduction in endangered ungulates: preservation of genetic variation through the organization of genetic resource banks. Reprod. Domest. Anim., 2006, 41: 82-89 (doi: 10.1111/j.1439-0531.2006.00772.x).

13. Ha nk s J. Conservation strategies for Africa's large mammals. Reprod. Fert. Develop., 2001, 13(7-8): 459-468. 
14. Singina G.N., Volkova N.A., B ag irov V.A., Zi novieva N.A. Cryobanking of somatic cells in conservation of animal genetic resources: prospects and successes (review). Agricultural Biology, 2014, 6: 3-14 (doi: 10.15389/agrobiology.2014.6.3eng) (in Engl.).

15. B l a c kburn H.D. Development of national animal genetic resource programs. Reprod. Fert. Develop., 2004, 16: 27-32 (doi: 10.10371/RD03075).

16. Hi e m stra S.J., van de r Le nde T., Wo e lde rs H. The potential of cryopreservation and reproductive technologies for animal genetic resources conservation strategies. Proc. Int. Workshop «The role of biotechnology for the characterisation and conservation of crop, forestry, animal and fishery genetic resources» (Italy, 5-7 March 2005). Turin, 2005: 25-36.

17. B o e t t c he r P.J., S t e 11 a A., P izzi F., Gandini G. The combined use of embryos and semen for cryogenic conservation of mammalian livestock genetic resources. Genet. Sel. Evol., 2005, 37(6): 657-675 (doi: 10.1186/1297-9686-37-7-657).

18. Ni e ma n n H., L u c a s- H a h n A. Somatic cell nuclear transfer cloning: practical applications and current legislation. Reprod. Domest. Anim., 2012, 47(5): 2-10 (doi: 10.1111/j.14390531.2012.02121.x).

19. B l a c k b u r n H.D. Genebank development for the conservation of livestock genetic resources in the United States of America. Livestock Sci., 2009, 120: 196-203 (doi: 10.1016/j.livsci.2008.07.004).

20. Mariante A., Albuquerque M., Egito A., McManus C., Lopes M., Pai$\mathrm{v}$ a S. Present status of the conservation of livestock genetic resources in Brazil. Livestock Sci., 2009, 120: 204-212 (doi: 10.1016/j.livsci.2008.07.007).

21. M a rty nik E. Animal genetic resources in Poland: successes and obstacles. Proc. Workshop "International strategic programs for the conservation of animal genetic resources for food and agriculture». C. Lessard (ed.). Vancouver, B.C., 2010: 29-35 (ISBN: 978-0-88880-566-9).

22. Richards K., Lessard C., Plante Y., Anzar M. Canadian animal genetic resources program. Proc. Workshop «International strategic programs for the conservation of animal genetic resources for food and agriculture». C. Lessard (ed.). Vancouver, B.C., 2010: 12-18 (ISBN: 978-0-88880-566-9).

23. Nemtsev A.S., Rautian G.S., Puzachenko A.Yu., Sipko T.P., Kalabushkin B.A., Mironenko I.V. Zubr na Kavkaze [Bison in the Caucasus]. Moscow, 2003 (in Russ.).

24. Flint V.E., B elousova I.P., Pererva V.I., Kaz'min V.D., Kise le va E.G., Kud ry avt s e v I.V., Pi roz h k ov N.V., S i p k o T.G. Strategiya sokhraneniya zubrov $v$ Rossii [Strategy for bison preservation in Russia]. Moscow, 2002 (in Russ.).

25. I o l c hi ev B.S., S trekozov N.I., Abilov A.I., Klenovitski i P.M., S ipko T.P. Sokhranenie genofonda zubrov $i$ ikh ispol'zovanie $v$ mezhvidovoi gibridizatsii [Bison: gene pool preservation and use in interspecies hybridization]. Dubrovitsy, 2005 (in Russ.).

26. $\mathrm{N}$ is h i J.S. A Review of best practices and principles for bison disease issues: greater Yellowstone and Wood Buffalo areas. Wildlife Conservation Society and American Bison Society (ABS), ABS Working Paper No. 3. Bronx, NY, USA, 2010.

27. M c Farlan e K., Wils o n G.A., N is hi J.S. Management strategies for conservation of genetic diversity in wood bison (Bison bison athabascae). File Report No. 135. Department of Environment and Natural Resources, Government of the Northwest Territories, Yellowknife, Northwest Territories, Canada, 2006.

28. Shury T.K., W o o d l e y S.J., R e y nold s H.W. Proceedings of the Bison Diseases Technical Workshop. Parks Canada, Gatineau, Quebec, 2005.

29. Abilov A.I., Ernst L.K., Strekozov N.I., Kononov V.P., Sipko T.P. Metodicheskie rekomendatsii po polucheniyu gibridov putem osemeneniya domashnikh korov (Vos taurus) «epididimal'nym semenem» dikikh zubrov (Bison bonasus) [Hybridisation of cows (Vos taurus) with wild bison (Bison bonasus) using epididymal semen - puidelines]. Dubrovitsy, 1994 (in Russ.).

30. Strekozov N.I., I o l chiev B.S., Abilov A.I., Vinogradov V.N., K is e le v a E.G., S i p k o T.P. Doklady RASKHN, 1997, 6: 28-29 (in Russ.).

31. I o lc hiev B.S., A b i lov A.I., S tre k o zov N.I. Doklady RASKHN, 2004, 5: 35-36. Available http://elibrary.ru/item.asp?id=18179672. No date (in Russ.).

32. Shishova N.V., Abilov A.I., Gakhova E.N., Maksudov G.Yu. Veterinarnaya patologiya, 2007, 20(1): 34-36. Available http://elibrary.ru/item.asp?id=17012920. No date (in Russ.).

33. Petrunkina A.M., Topfer Petersen E. Heterogeneous osmotic behaviour in boar sperm populations and its relevance for detection of changes in plasma membrane. Reprod. Fertil. Dev., 2000, 12: 297-305 (doi: 10.1071/RD00087).

34. Thompson L.A., B rook P.F., Warren M., B arrat C., Cooke I. A morphometric comparison of the nuclear morphology of fresh and frozen-thawed human zona-bound and unbound sperm. J. Androl., 1994, 15: 337-342 (doi: 10.1002/j.1939-4640.1994.tb00461.x).

35. Gravance C.G., Casey M.E., C as e P.J. Pre-freeze bull sperm head morphometry related with post-thaw fertility. Anim. Reprod. Sci., 2009, 114: 81-88 (doi: 10.1016/j.anireprosci.2008.09.014).

36. Peña F.J., Saravia F., García Herreros M., Núñezmartínez I., Tapia J.A., Johannisson A., Wallgren M., Rodríguez-Martínez H. Identification of sperm morphometric subpopulations in two different portions of the boar ejaculate and its relation to post thaw quality. J. Androl., 2005, 26: 716-723 (doi: 10.2164/jandrol.05030). 
37. García Herreros M., Baryn F.J., Aparicio I.M., Santos A.J., García Ma rí n L.J. Morphometric changes in boar spermatozoa induced by cryopreservation. Int. J. Androl., 2008, 31: 490-498 (doi: 10.1111/j.1365-2605.2007.00794.x).

38. Arruda R.P., B all B.A., Gravance C.G., G a r cia R.P., Liu I.K. Effects of extenders and cryoprotectants on stallion sperm head morphometry. Theriogenology, 2002, 58: 252-256 (doi: 10.1016/S0093-691X(02)00858-0).

39. P eña A.I., Lugild e L.L., B arrio M., Herradon P.G., Quintela L.A. Effects of Equex from different sources on post thaw survival, long evity and intracelular $\mathrm{Ca}^{2+}$ concentration of dog spermatozoa. Theriogenology, 2003, 59: 1725-1739 (doi: 10.1016/S0093-691X(02)01233-5).

40. Thomas C., Garner D., De Jarnette J., Marshall C. Fluorometric assessments of acrosomal integrity and viability in cryopreserved bovine spermatozoa. Biol. Reprod., 1997, 56: 991-998.

41. Vi n o g r a d o v V.N., S t r e k o z o v N.I., A b i lov A.I. et al. Natsional'naya tekhnologiya zamorazhivaniya i ispol'zovaniya spermy plemennykh bykov-proizvoditelei [National technology of freezing and use of pedigree bull sires]. Moscow, 2009 (in Russ.).

42. I o l c hiev B.S., B a gi rov V.A., Kle novitskij P.M., Kononov V.P., Nasibo v Sh.N., Vo e vodin V.A. Dostizheniya nauki $i$ tekhniki APK, 2011, 9: 54-56. Available http://elibrary.ru/item.asp?id=16911151. No date (in Russ.).

43. I o l c hi ev B.S., B ag i rov V.A., Klenovitskiy P.M., Kononov V.P., Tadzie $\mathrm{v}$ a A.V. The index of dna fragmentation in sperm chromatin as a criteria to predict an individual fecundity in bulls sires. Agricultural Biology, 2012, 4: 31-35 (doi: 10.15389/agrobiology.2012.4.31eng) (in Eng.).

44. T a d z h i e v a A.V., S u 1 i m a N.N. Vestnik RUDN, seriya Agronomiya i zhivotnovodstvo, 2015, 4: 89-92. Available http://elibrary.ru/item.asp?id=24834978. No date (in Russ.).

45. B o i k o E.V., K o r o p e t s L.A. Vestnik Bryanskoi gosudarstvennoi sel'skokhozyaistvennoi akademii, 2015, 3-1: 4-8. Available dostupa: http://elibrary.ru/item.asp?id=23478336. No date (in Russ.).

46. A y b a zov M.M., Aks e nova P.V., S e rdyuk ov I.G. Sel'skokhozyaistvennye zhivotnye, 2013, 4: 9-10. Available http://elibrary.ru/item.asp?id=20804276. No date (in Russ.).

47. Ozkavukcu S., Erdemli E., Isik A., Oztuna D., Karahuseyinoglu S. Effects of cryopreservation on sperm parameters and ultrastructural morphology of human spermatozoa. J. Assist. Reprod. Genet., 2008, 25(8): 403-411 (doi: 10.1007/s10815-008-9232-3).

48. Ha m madeh M.E., Askari A.S., Georg T., Ros enbaum P., S c hmidt W. Effect of freeze-thawing procedure on chromatin stability, morphological and membrane integrity of human spermatozoa in fertile and subfertile men. Int. J. Androl., 1999, 22: 155-162 (doi: 10.1046/j.1365-2605.1999.00162.x).

49. Buhr M.M., Fis e r P., B a i le y J.L., C u rt is E.F. Cryopreservation in different concentrations of glycerol alters boar sperm and their membranes. J. Androl., 2001, 22: 961-969 (doi: 10.1002/j.1939-4640.2001.tb03436.x).

50. Gi 1 mo re J.A., Li u J., G a o D.Y., C rits e r J.K. Determination of optimal cryoprotectants and procedures for their addition and removal from human spermatozoa. Hum. Reprod., 1997, 12: 112-118 (doi: 10.1093/humrep/12.1.112).

51. Che now et h P.J. Genetic sperm defects. Theriogenology, 2005, 64: 457-468 (doi: 10.1016/j.theriogenology.2005.05.005).

52. Dahlbom M., Andersson M., Viertula M., Alanko M. Morphometry of normal and teratozoospermic canine sperm heads using an image analyser: work in progress. Theriogenology, 1997, 48: 687-698 (doi: 10.1016/S0093-691X(97)00284-7).

53. B o e rsma A.A., B raun J., S tolla R. Influence of random factors and two different staining procedures on 1 computer-assisted sperm head morphometry in bulls. Reprod. Domest. Anim., 1999, 34: 77-82 (doi: 10.1111/j.1439-0531.1999.tb01387.x).

54. Purwantara B., Arifiantini R.I., Riy adhi M. Sperm morphological assessments of Friesian Holstein bull semen collected from three artificial insemination centers in Indonesia. Journal of the Indonesian Tropical Animal Agriculture, 2010, 2: 89-94 (doi: 10.14710/jitaa.35.2.90-94).

55. Söderquist L., J a n s o n L., H e e rd M., Ei na rs s o n S. Influence of season, age, breed and some other factors on the variation in sperm morphological abnormalities in Swedish dairy AI bulls. Anim. Reprod. Sci., 1996, 44: 91-98.

56. P a d ri k P., J a a k m a U. Sperm morphology in Estonian Holstein dairy bulls, factors affecting it and relation to fertility. Agraarteadus, 2002, 13: 243-256. Available http://agrt.emu.ee/pdf/2002_4_padrik.pdf. No date.

57. Hallap T., Nagy S., H llrd M., Jaakma U., Johannisson A., RodríquezMartínez H. Sperm chromatin stability in frozen-thawed semen is maintained over age in AI bulls. Theriogenology, 2005, 63: 1752-1763 (doi: 10.1016/j.theriogenology.2004.08.001).

58. Makhzoomi A., Lundeheim N., Ha ard M., Rodríquez-Martínez H. Sperm morphology and fertility of progeny-tested AI dairy bulls in Sweden. Theriogenology, 2008, 70: 682-691 (doi: 10.1016/j.theriogenology.2008.04.049).

59. S a r d e r M.J.U. Effects of age, body weight, body condition and scrotal circumference on sperm abnormalities of bulls used for artificial insemination (AI) programme in Bangladesh. University Journal of Zoology, Rajshahi University, 2008, 27: 73-78 (doi: 10.3329/ujzru.v27i0.1959). 
60. Benchaib M., Braun V., Lornage J., Hadj S., Salle B., Herve L., François Guéri n J. Sperm DNA fragmentation decreases the pregnancy rate in an assisted reproductive technique. Hum. Reprod., 2003, 18(5): 1023-1028 (doi: 10.1093/humrep/deg228).

61. Morris I.D., I lot t S., Dix o n L., B ris o n D.R. The spectrum of DNA damage in human sperm assessed by single cell gel electrophoresis (Comet assay) and its relationship to fertilization and embryo development. Hum. Reprod., 2002; 17: 990-998 (doi: 10.1093/humrep/17.4.990).

62. To msu M., Sharma V., Mille r D. Embryo quality and IVF treatment outcomes may correlate with different sperm comet assay parameters. Hum. Reprod., 2002, 17(7): 1856-1862 (doi: 10.1093/humrep/17.7.1856).

63. Filatov M.V., Semenova E.V., Vorob'eva O.A., Leont'eva O.A., Drobc he n k o E.A. Relationship between abnormal sperm chromatin packing and IVF results. Mol. Hum. Reprod., 1999, 5: 825-830 (doi: 10.1093/molehr/5.9.825).

64. Host E., Lindenberg S., S midt-Jensen S. The role of DNA strand breaks in human spermatozoa used for IVF and ICSI. Acta Obstetricia et Gynecologica Scandinavica, 2000, 79: 559-563 (doi: 10.1034/j.1600-0412.2000.079007559.x).

65. Larson K.L., D e Jonge C.J., B arnes A.M., Jost L.K., Eve n so n D.P. Sperm chromatin structure assay parameters as predictors of failed pregnancy following assisted reproductive techniques. Hum. Reprod., 2000, 15(8): 1717-1722 (doi: 10.1093/humrep/15.8.1717).

66. G a li mov Sh.N., A mi rova Z.K., Gali m ov a E.F. Problemy reproduktsii, 2005, 2: 1922. Available http://elibrary.ru/item.asp?id=9157231. No date (in Russ.).

67. Eve n s o n D.P., J o st L.K., C orzet t M., B a lhorn R. Characteristics of human sperm chromatin structure following an episode of influenza and high fever: a case study. J. Androl., 2000, 21: 739-746 (doi: 10.1002/j.1939-4640.2000.tb02142.x).

68. B o e-Hansen G.B., Ersboll A.K., Greve T., Christense n P. Increasing storage time of extended boar semen reduces sperm DNA integrity. Theriogenology, 2005, 63: 2006-2019 (doi: 10.1016/j.theriogenology.2004.09.006).

69. B o c h e nek M., H e rja n T., O k y ls ki A., S m o r ąg Z. Sperm chromatin abnormalities after semen sexing procedure - preliminary results. Havemeyer Foundation Monograph Series, 2006, 18: 13-14. 